In cooperation with

New York State Department of Environmental Conservation New York State Department of Transportation New York City Department of Environmental Protection

\title{
Regionalized Equations for Bankfull Discharge and Channel Characteristics of Streams in New York State: Hydrologic Region 6 in the Southern Tier of New Park
}

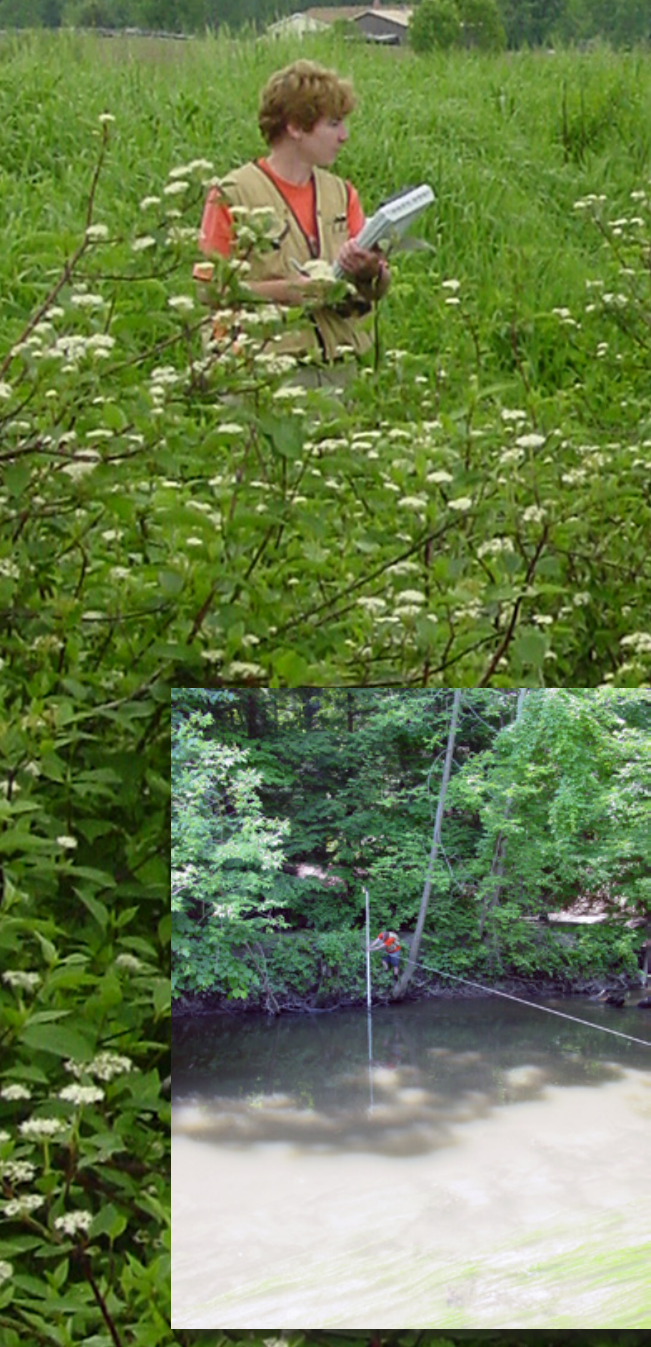

Scientific Thvestigations Report 2005-5100

U.S.Department of the Interior

U.S. GeologicarSurvey
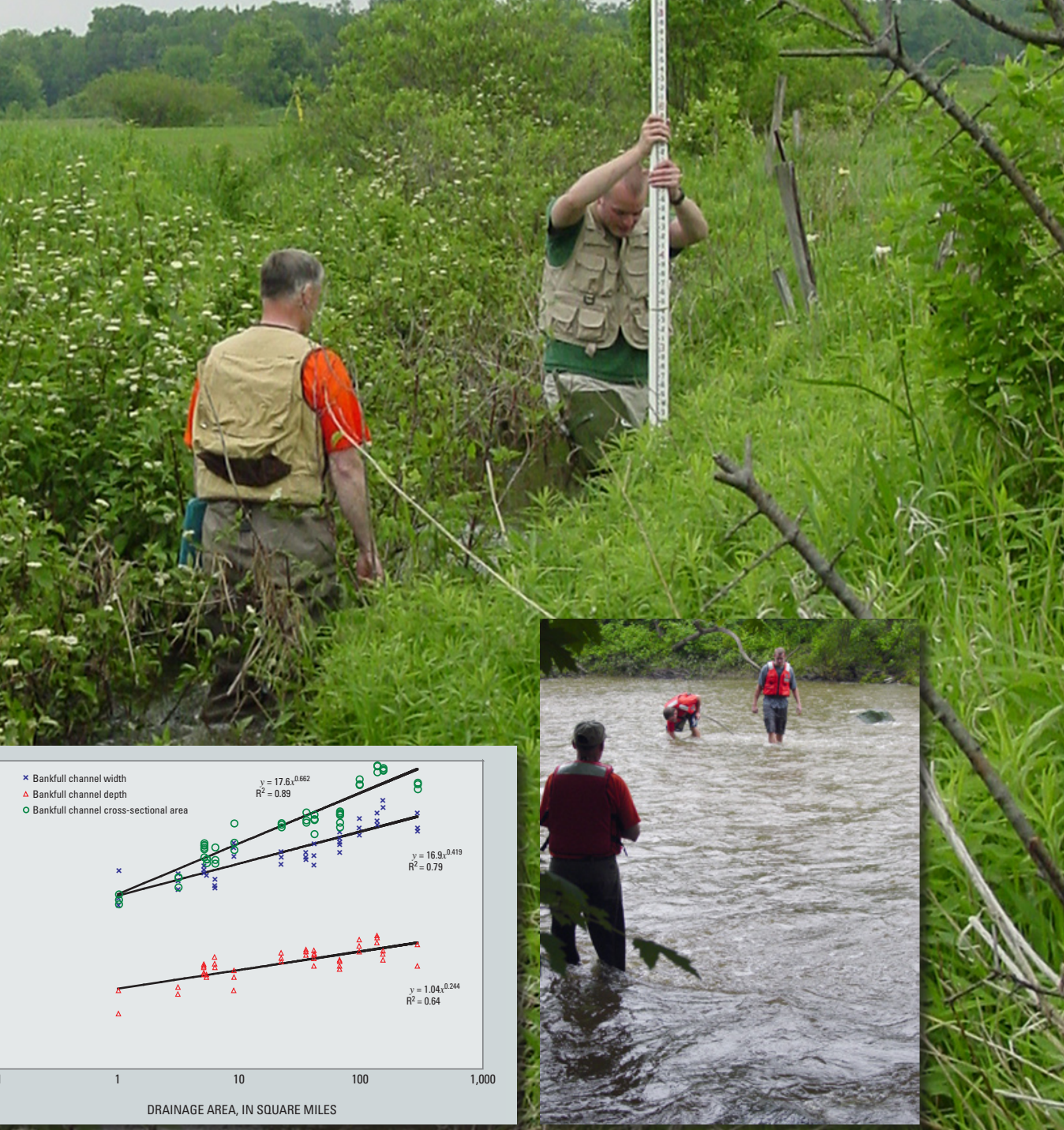
This page has been left blank intentionally. 


\section{Regionalized Equations for Bankfull Discharge and Channel Characteristics of Streams in New York State: Hydrologic Region 6 in the Southern Tier of New York}

By Christiane I. Mulvihill, Anne G. Ernst, and Barry P. Baldigo

Scientific Investigations Report 2005-5100

In cooperation with

New York State Department of Environmental Conservation

New York State Department of Transportation

New York City Department of Environmental Protection

U.S. Department of the Interior

U.S. Geological Survey 


\section{U.S. Department of the Interior \\ Gale A. Norton, Secretary \\ U.S. Geological Survey \\ P. Patrick Leahy, Acting Director}

\section{U.S. Geological Survey, Reston, Virginia: 2005 \\ Version 1.01}

For additional information about this report write to:

U.S. Geological Survey

425 Jordan Road

Troy, NY 12180

Email: askny@usgs.gov

World Wide Web: http://ny.usgs.gov/

For more information about the USGS and its products:

Telephone: 1-888-ASK-USGS

World Wide Web: http://www.usgs.gov/

Any use of trade, product, or firm names in this publication is for descriptive purposes only and does not imply endorsement by the U.S. Government.

Although this report is in the public domain, permission must be secured from the individual copyright owners to reproduce any copyrighted materials contained within this report.

Suggested citation:

Mulvihill, C.I., Ernst, A.G., and Baldigo, B.P., 2005, Regionalized Equations for Bankfull Discharge and Channel

Characteristics of Streams in New York State: Hydrologic Region 6 in the Southern Tier of New York: U.S. Geological Survey Scientific Investigations Report 2005-5100, 14 p., online only. 


\section{Contents}

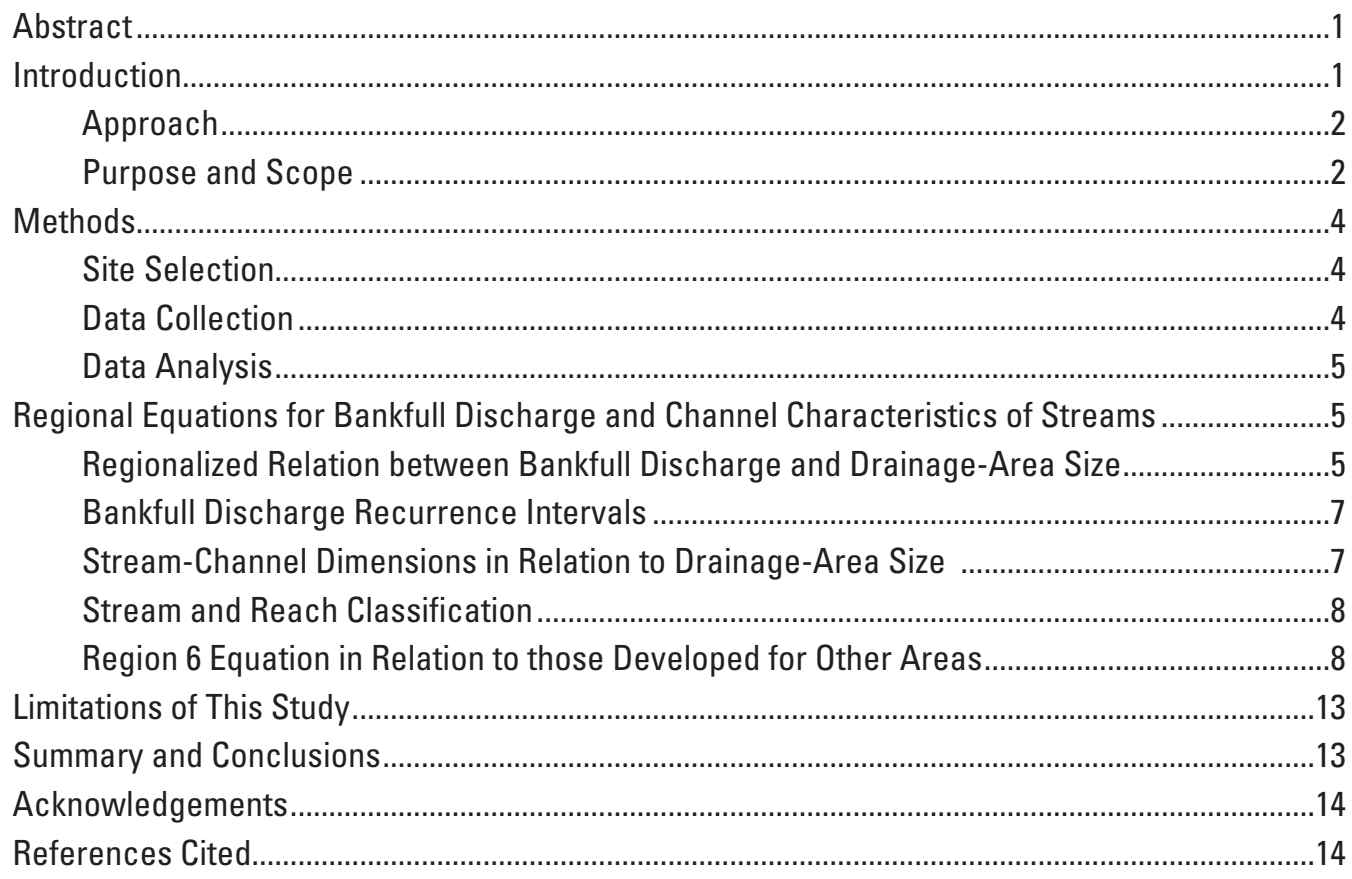

\section{Figures}

1. Map showing hydrologic regions in New York: A. Hydrologic-region boundaries as defined by Lumia (1991). B. Locations of the 11 active and 3 inactive streamflow-gaging stations used in 2002-03 stream survey in Region 6 .....

2. Graph showing bankfull discharge as a function of drainage-area size for streams surveyed in Region 6 in New York, with 95-percent confidence and prediction intervals for all sites.

3. Graph showing bankfull channel width, depth, and cross-sectional area as a function of drainage-area size for all streams surveyed in Region 6 in New York, with best-fit lines, regression equations, and coefficient of determination $\left(R^{2}\right)$ values

4. Graph showing mean channel dimensions as a function of drainage-area size for streams in Region 6 in New York, with 95-percent confidence and prediction intervals: A. Bankfull channel width. B. Bankfull channel depth. C. Bankfull channel cross-sectional area......

5. Graph showing bankfull discharge as a function of drainage-area size for Region 6 in New York, and published curves for four other regions in the Northeast...

\section{Tables}

1. Characteristics of streamflow-gaging stations surveyed in Region 6 in New York, 2002-03

2. Stream classification and bankfull channel-geometry data for cross sections at the 14 streamflow-gaging stations surveyed in Region 6 in New York, 2002-03 


\section{Conversion Factors and Datum}

\section{Inch/Pound to SI}

\begin{tabular}{lcl}
\hline Multiply & By & To obtain \\
\hline & Length & \\
inch (in.) & 25.4 & millimeter $(\mathrm{mm})$ \\
foot (ft) & 0.3048 & meter $(\mathrm{m})$ \\
mile (mi) & 1.609 & kilometer $(\mathrm{km})$ \\
foot per second $(\mathrm{ft} / \mathrm{s})$ & 0.3048 & meter per second $(\mathrm{m} / \mathrm{s})$ \\
& Area & \\
square mile $\left(\mathrm{mi}^{2}\right)$ & 2.590 & square kilometer $\left(\mathrm{km}^{2}\right)$ \\
& Flow Rate & \\
cubic foot per second $\left(\mathrm{ft}^{3} / \mathrm{s}\right)$ & 0.02832 & cubic meter per second $\left(\mathrm{m}^{3} / \mathrm{s}\right)$ \\
\hline
\end{tabular}

Temperature in degrees Celsius $\left({ }^{\circ} \mathrm{C}\right)$ may be converted to degrees Fahrenheit $\left({ }^{\circ} \mathrm{F}\right)$ as follows: ${ }^{\circ} \mathrm{F}=\left(1.8 x^{\circ} \mathrm{C}\right)+32$

Temperature in degrees Fahrenheit $\left({ }^{\circ} \mathrm{F}\right)$ may be converted to degrees Celsius $\left({ }^{\circ} \mathrm{C}\right)$ as follows: ${ }^{\circ} \mathrm{C}=\left({ }^{\circ} \mathrm{F}-32\right) / 1.8$

Vertical coordinate information is referenced to the North American Vertical Datum of 1988 (NAVD 88).

Horizontal coordinate information is referenced to the North American Datum of 1983 (NAD 83). 


\title{
Regionalized Equations for Bankfull Discharge and Channel Characteristics of Streams in New York State: Hydrologic Region 6 in the Southern Tier of New York
}

\author{
By Christiane I. Mulvihill, Anne G. Ernst, and Barry P. Baldigo
}

\section{Abstract}

Equations that relate bankfull discharge and channel characteristics (width, depth, and cross-sectional area) to drainage-area size at gaged sites are needed to define bankfull discharge and channel dimensions at ungaged sites and to provide information for watershed assessments, streamchannel classification, and the design of stream-restoration projects. Such equations are most accurate if derived from streams within an area of uniform hydrologic, climatic, and physiographic conditions and applied only within that region. In New York State, eight hydrologic regions were previously defined on the basis of similar high-flow (flood) characteristics. This report presents drainage areas and associated bankfull characteristics (discharge and channel dimensions) for surveyed streams in southwestern New York (Region 6).

Stream-survey data and discharge records from 11 active (currently gaged) sites and 3 inactive (discontinued) sites were used in regression analyses to relate bankfull discharge and bankfull channel width, depth, and cross-sectional area to the size of the drainage area. The resulting equations are:

bankfull discharge $\left(\mathrm{ft}^{3} / \mathrm{s}\right)=48.0\left(\text { drainage area, in } \mathrm{mi}^{2}\right)^{0.842}$ bankfull channel width $(\mathrm{ft})=16.9(\text { drainage area })^{0.419}$ bankfull channel depth $(\mathrm{ft})=1.04(\text { drainage area })^{0.244}$ bankfull channel cross-sectional area $\left(\mathrm{ft}^{2}\right)=17.6$ (drainage area $)^{0.662}$

The coefficient of determination $\left(\mathrm{R}^{2}\right)$ for these four equations were $0.90,0.79,0.64$, and 0.89 , respectively. The high correlation coefficients for bankfull discharge and cross-sectional area indicate that much of the variation in these variables is explained by the size of the drainage area. The smaller correlation coefficients for bankfull channel width and depth indicate that other factors also affect these relations. Recurrence intervals for the estimated bankfull discharge of each stream ranged from 1.01 to 2.35 years; the mean recurrence interval was 1.54 years. The 14 surveyed streams were classified by Rosgen stream type; most were $\mathrm{C}$-type reaches, with occasional B-type reaches. The Region 6 equation (curve) for bankfull discharge was compared with equations previously developed for four other large areas in New York State and southeastern Pennsylvania. The differences among results indicate that, although the equations need to be refined by region before being applied by water-resources managers to local planning and design efforts, similar regions have similar relations between bankfull discharge and channel characteristics.

\section{Introduction}

Streambank erosion and the resulting sedimentation in streams can affect the water quality of reservoirs and endanger private and public lands and associated infrastructure across New York State. Many streams throughout New York State that have abnormally high rates of bank erosion and sedimentation are undergoing restoration efforts to improve bank and bed stability (Miller and Davis, 2003). Stream restorations have traditionally consisted of procedures such as straightening, widening, and deepening the channel, hardening the banks, and imposing static stream geometry-all of which can cause permanent ecological disruption. Recent stream-restoration projects, however, have begun to use an approach that strives toward replication of stable-reach characteristics, such as the relation between drainage-area size and channel cross-section dimensions, and the relations among channel dimensions, flow patterns, and water-surface profiles. Equations (models or curves) defining these relations developed from stable-reach data at gaged streams can provide a basis for channel restorations in nearby unstable, ungaged streams and for replication of geomorphically stable reaches that support healthy ecosystems.

The most important variable in calculating the relations between drainage-area size and stream-channel dimensions is bankfull discharge, which corresponds to the point of transition between the channel and its flood plain (Leopold and others, 1964), and is the stage or flow at which the stream is about to overtop its banks onto the flood plain (Leopold and others, 1964; Leopold, 1994). Bankfull discharge is reported to occur every 1 to 2 years, or 1.5 years 
 \\ Regionalized Equations for Bankfull Discharge and Channel Characteristics of Streams in New York State: Hydrologic Region 6 in the Southern Tier of New York}

on average (Rosgen, 1994), and is the flow that moves the most sediment over time, because of the combination of its force and frequency (Wolman and Miller, 1960; Leopold, 1994). The characteristics of bankfull discharge affect the relations between drainage-area size and stream-channel dimensions in two ways. First, bankfull discharge often occurs at a relatively discrete and identifiable stage and, therefore, provides a basis for a system to classify streams in terms of channel dimensions at bankfull stage (Rosgen, 1996). Second, relations between drainage area and discharge, and between drainage area and channel dimensions, are relatively constant at bankfull stage in stable streams of the same class and within the same hydrophysiographic region (Leopold and others, 1964; Rosgen, 1996).

Predicting stable-channel characteristics for an unstable, ungaged stream requires equations based on data from stable, gaged streams that are close to the ungaged stream; are subject to similar precipitation rates and climatic conditions; and have drainage areas with similar soils, recharge patterns, channel patterns, and physiographic characteristics. Deriving channelgeometry equations from streams within a given hydrologic region can minimize variance in each variable and increase the accuracy of the equations.

The New York State Hydrologic and Habitat Modification (HHM) subcommittee of the New York State Nonpoint-Source Coordinating Committee (NSCC) is overseeing a statewide cooperative effort to develop such equations using a protocol developed by the New York City Department of Environmental Protection Stream Management Program (NYCDEP-SMP; Miller and Davis, 2003; Powell and others, 2003). Similar efforts are being conducted in other parts of North America, including Vermont (Jaquith and Kline, 2001), southern Ontario (Annable, 1996), and the Pennsylvania-Maryland Piedmont area (White, 2001). These equations, which reflect localized precipitation rates, hydrologic conditions, physiographic characteristics, and soil properties, are expected to provide more reliable results than the currently available channel-geometry equations that represent widespread geographic regions, such as the eastern United States (Dunne and Leopold, 1978).

\section{Approach}

In 2001, the U.S. Geological Survey (USGS), in cooperation with the New York State Department of Environmental Conservation (NYS DEC), and the New York State Department of Transportation (NYS DOT), and with assistance from the New York City Department of Environmental Protection (NYC DEP), the Delaware County Soil and Water Conservation District (DCSWCD) and the Greene County Soil and Water Conservation District (GCSWCD), began a 6-year study to define the relations between drainage-area size and channel characteristics for the eight hydrologic regions of New York State (excluding Long Island) (fig. 1A) that were previously established to predict flood flows of unregulated streams (Lumia, 1991). Boundaries of the hydrophysiographic regions from Lumia (1991) were used as preliminary hydrologic-region boundaries to group streams with similar characteristics. Equations have been developed for Regions 4 and 4a (Miller and Davis, 2003) and Region 5 (Westergard and others, 2005). The objectives of the continuing study are to (1) complete bankfull surveys on selected streams in all eight regions to verify and (or) redefine these boundaries, (2) assess all streams for key features of the stream-classification system of Rosgen (1996); namely, channel-entrenchment ratio (ratio of flood-plain width to bankfull-channel width), channel-width-to-depth ratio, watersurface slope, channel materials, and channel sinuosity (ratio of stream length to valley length), and (3) assess statewide bankfull equations by grouping channel-geometry relations across the eight regions by stream type in accordance with the Rosgen stream-classification system (Miller and Davis, 2003).

Rosgen's (1996) stream-classification system was created to provide consistent stream descriptions for use in evaluations of channel stability and in the design and simulation of stable conditions in ungaged stream reaches. The geomorphologic characteristics defined by Rosgen (1996) that correspond to bankfull stage were chosen for their consistency among streams having similar physiographic conditions for a given drainage-basin size, and among streams subject to similar climatic conditions (Rosgen, 1994, 1996).

Region 6 (fig. 1), the fourth of the eight hydrologic regions to be inspected for this study, extends north to the southern end of the Finger Lakes region and to Tonawanda Creek and its tributaries, south to the New York-Pennsylvania border, west to Lake Erie, and east to the Tioughnioga and Chenango Rivers and their tributaries (Lumia, 1991). Region 6 contained only 11 actively gaged sites that met the selection criteria; therefore, records from three inactive gaged sites also were used in the development of the equations. All sites were on unregulated streams and had at least 10 years of discharge record.

The eight hydrophysiographic regions used by Lumia (1991) were based primarily on a residual analysis of a statewide multiple linear regression analysis that related the 50-year peak-discharge recurrence interval to the following basin characteristics: drainage-area size, main-channel slope, percent basin storage, mean annual precipitation, percentage of basin covered by forest area, mean main-channel elevation, and a basin-shape index. The region boundaries were based on these residuals and regional differences in geological and physiographic conditions. These boundaries will later be compared with those developed from bankfull-survey data collected during this and other studies, and can be adjusted, if needed.

\section{Purpose and Scope}

This report (1) describes the methods of site selection and data collection and analysis; (2) presents the relations between 


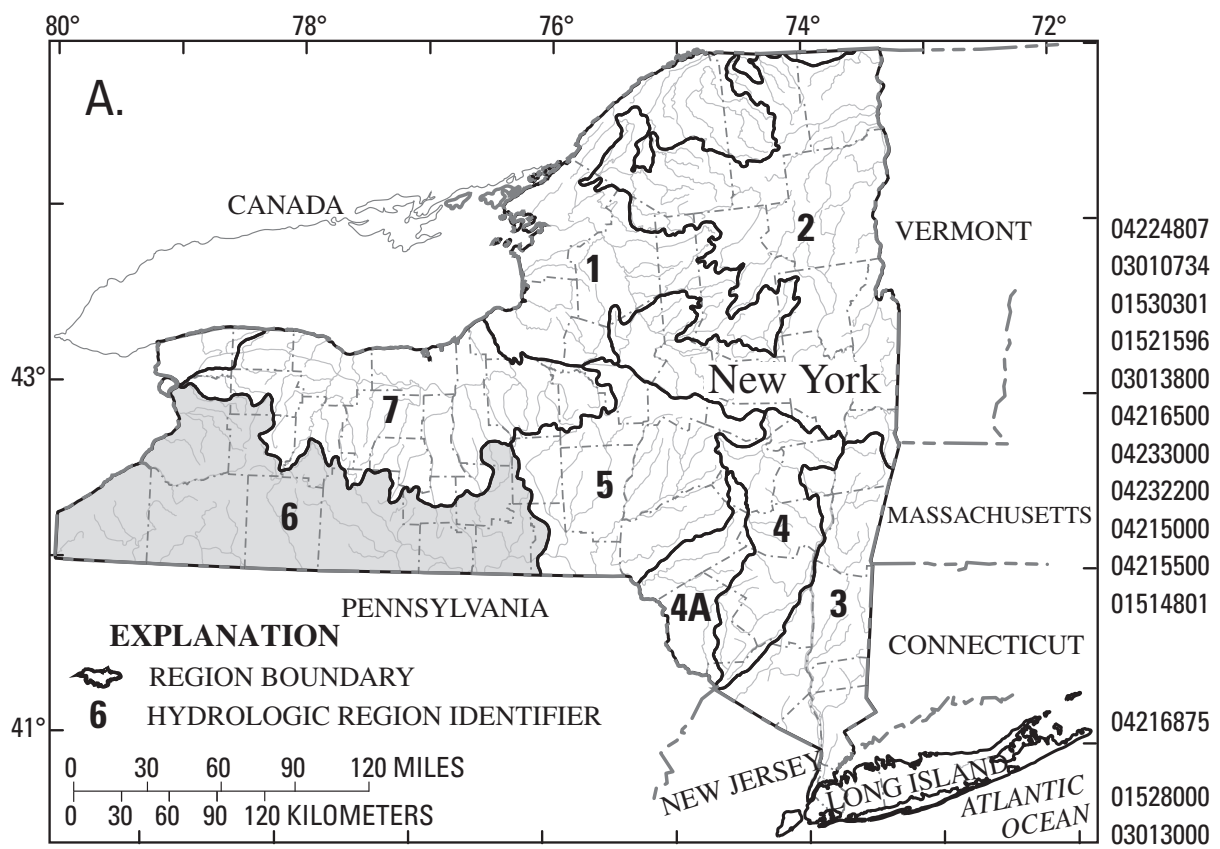

\section{ACTIVE SITES}

Stony Brook Tributary at South Dansville Ischua Creek Tributary near Machias Cuthrie Run near Big Flats

Big Creek near Howard

Ball Creek at Stow

Little Tonawanda Creek at Linden

Cayuga Inlet near Ithaca

Catherine Creek at Montour Falls

Cayuga Creek near Lancaster

Cazenovia Creek at Ebenezer

Catatonk Creek northwest of Owego

\section{INACTIVE SITES}

Little Tonawanda Creek Tributary near Batavia

Fivemile Creek near Kanona

Conewango Creek at Waterboro

Base from U.S. Geological Survey digital data

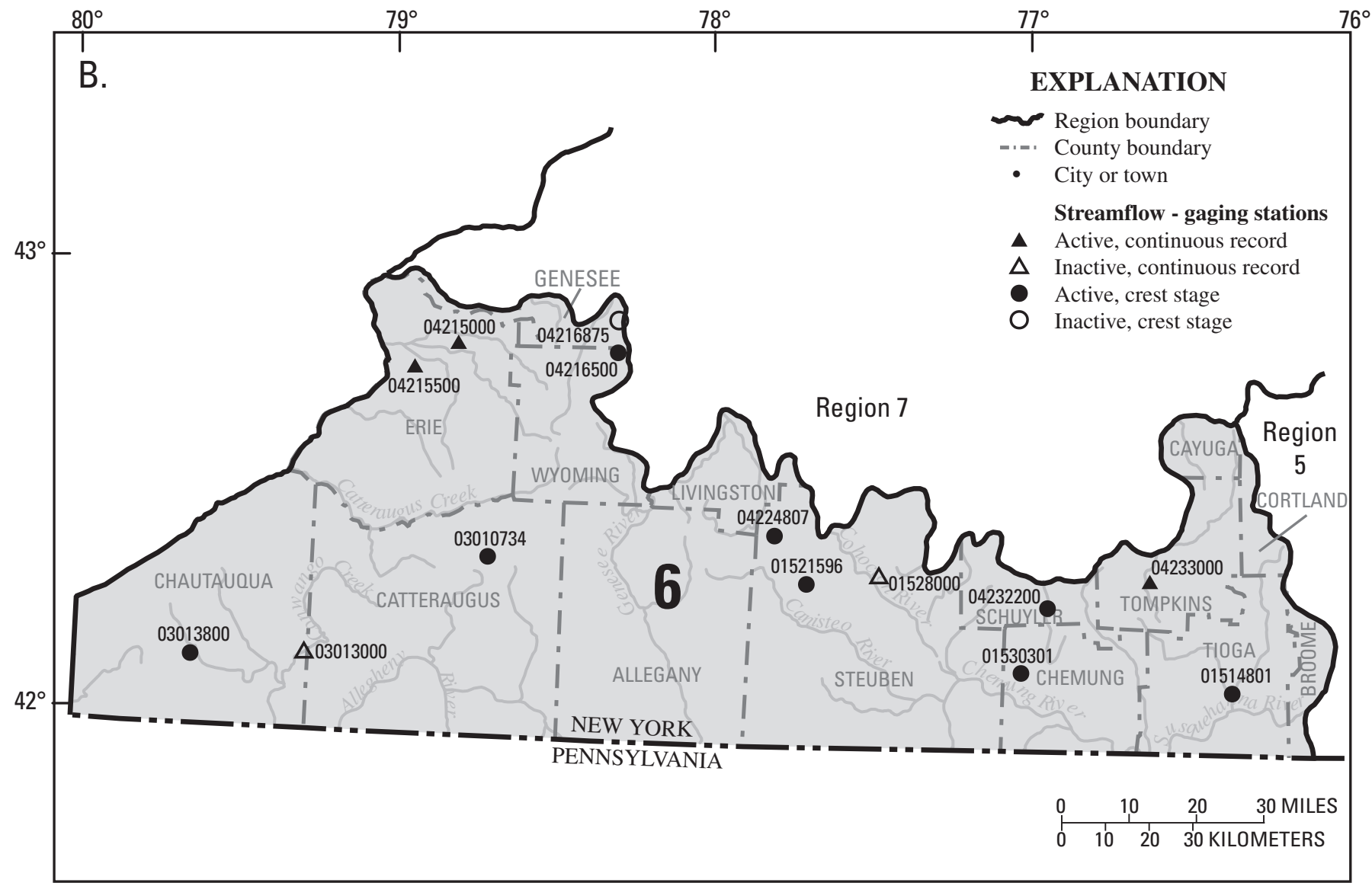

Base from U.S. Geological Survey digital data

Figure 1. Map showing hydrologic regions in New York: A. Hydrologic-region boundaries as defined by Lumia (1991). B. Locations of the 11 active and 3 inactive streamflow-gaging stations used in 2002-03 stream survey in Region 6. 
Regionalized Equations for Bankfull Discharge and Channel Characteristics of Streams in New York State: Hydrologic Region 6 in the Southern Tier of New York

drainage area and bankfull width, depth, cross-sectional area, and discharge for 14 streams in Region 6, and (3) compares bankfull-discharge equations developed for Region 6 in this study with previously developed equations for Regions 4, 4a, and 5 in New York State and for southeastern Pennsylvania.

\section{Methods}

Fourteen sites were surveyed during the 2002-03 field season. The methods used to collect and analyze the data in this report are described in detail in Powell and others (2004) and summarized below.

\section{Site Selection}

The streams were selected to cover a wide range of drainage-area sizes so that the resulting equations would be applicable to a majority of streams within the hydrologic region. Other selection criteria (Miller and Davis, 2003) for each study reach are listed below:

- Every reach must have a USGS streamflow-gaging station with at least 10 consecutive years of annual peak-discharge data.

- Every reach must be primarily alluvial, unregulated, and consist of a single channel at bankfull stage.

- Every reach must contain at least two sequences of a pool and a riffle, or be at least 20 bankfull widths in length.

- Every reach must have readily identifiable bankfull indicators.

- Every reach must meet the minimum requirements for slope-area calculation of discharge (uniform channel geometry; flow contained in single, trapezoidal channel; and watersurface elevation drop between cross sections of at least $0.50 \mathrm{ft}$ (Dalrymple and Benson, 1967), so that surveyed data can reliably be used in hydraulic analyses and calculation of bankfull discharge.

- The gage must be in the reach.

- Every reach should represent a single Rosgen (1996) stream type, if possible.

Not all USGS gages are installed on geomorphically stable stream reaches because land-owner permission, access to the gage, and the need for the safe measurement of high flows often dictate where a gage is located. Thus, bridges or other structures in these reaches may cause localized channel instability near the gages. Two methods were used to determine channel stability at gages selected for this study. Active sites: channel stability was assessed through an inspection of the most recent analysis of discharge data for evidence of scour, deposition, and frequent shifting of bed material. Inactive sites: channel stability was assessed through three to five discharge measurements made during the study to define the stage-to-discharge relation (rating), which was compared with the last known rating from when the site was active. Appreciable discrepancy between these two ratings indicated channel instability.

The 14 selected sites were referred to as "calibration sites" because they were used to develop or calibrate the channel-geometry equations. Region 6 contained 30 active sites with 10 or more years of record, but 19 of these sites were determined, during site visits, to be unsuitable for gagecalibration surveys. Therefore, 3 sites that had been inactive for 8 to 17 years were added, to provide a total of 14 sites that covered a wide range of drainage-area sizes.

\section{Data Collection}

Preliminary reconnaissance of all sites entailed marking bankfull indicators, cross-section locations, and reach boundaries. Six bankfull indicators were used: (1) topographic break from vertical bank to flat flood plain, (2) topographic break from steep slope to gentle slope, (3) change in vegetation (for example, from treeless to trees), (4) textural change in sediment, (5) scour break, or elevation below which no fine debris (needles, leaves, cones, seeds) occurs, and (6) back of point bar, lateral bar, or low bench (Castro and Jackson, 2001; Miller and Davis, 2003). Identification of bankfull indicators was complicated at some locations by dense vegetation, which made indicators difficult to locate, or by the presence of various possible indicators at differing elevations at a given cross section. When this was the case, multiple indicators were flagged, and the data-analysis techniques described below were used to determine which bankfull stage was most accurate.

The upper and lower ends of the reach, and the locations of cross sections, were marked with rebar driven into the streambank above bankfull stage on one or both banks. Three or four cross sections at each site were placed in riffles or runs, away from channel-constricting structures such as bridges and culverts.

The preliminary reconnaissance was followed by a survey of each study reach, by methods described in Powell and others (2004). Longitudinal-profile and cross-sectional surveys were conducted at each reach. The longitudinal-profile survey included elevation measurements of rebar marking the upper and lower reach limits; all bankfull indicators; and the thalweg and water surface at each bankfull indicator, cross section, and pool-riffle transition. The cross-section surveys included measurements of bed and bank elevations, bankfullindicator elevations, rebar that marked cross sections, and the flood-plain width. The reference elevation for all surveys was the elevation used to define the stage-to-discharge relation at active sites and to develop the stage-to-discharge relation at inactive sites. Channel-bed material throughout the reach was characterized through a modified Wolman pebble count (Harrelson and others, 1994). 


\section{Data Analysis}

All field data were compiled for graphical analysis. Construction of the bankfull-elevation profile along each reach entailed plotting a best-fit line through the surveyed bankfullstage indicators. Multiple lines were plotted if bankfull indicators were present at more than one elevation, and the bankfull stage and associated discharge that best agreed with the 1.5-year bankfull recurrence interval were used.

At active sites, the bankfull stage at the gage or staff plate was derived as described above, and the corresponding bankfull discharge was taken from the most current stageto-discharge relation. At inactive sites, bankfull discharge was interpolated from newly developed stage-to-discharge relations that were extended to bankfull stage through Johnson's method (Kennedy, 1984). At all sites, estimates of bankfull discharge were verified through a hydraulic analysis of the bankfull geomorphologic data collected during the streamflow-gaging station calibration survey, as described below. Additional details are given in Powell and others (2004).

(1) The computer program NCALC (Jarrett and Petsch, 1985) was used to compute Manning's $n$, the roughness coefficient of the channel. Data required for this computation were: discharge from the stage-to-discharge relation, channel-bed and bankfull water-surface elevations at each cross section, and the distance along the thalweg between cross sections (Jarrett and Petsch, 1985). For this report, all bankfull water-surface elevations were taken from best-fit lines, rather than from surveyed bankfull indicators, to smooth local variations in slope that can result from intermittent channel controls like bedrock outcrops and debris piles.

(2) The computer program HEC-RAS (U.S. Army Corps of Engineer's Hydraulic Engineering Center River Analysis System; Brunner, 1997) was used to determine bankfull discharge by calculating water-surface elevation, as follows: first, the reference elevation for the survey was entered as the starting elevation, and Manning's $n$ (from the NCALC analysis), channel-bed elevations at each cross section, the distance along the thalweg between cross sections, and various estimated discharges were input for each cross section; the bankfull discharge chosen for that location was the discharge at the water-surface elevation (calculated by HEC-RAS) that most closely approximated the surveyed bankfull water-surface elevation; and finally, the average of these discharges from all cross sections in the reach was used as the bankfull discharge for the reach.

(3) The bankfull discharge obtained from the stage-todischarge relation was compared with the bankfull discharge obtained from the HEC-RAS analysis. If the two discharges differed by 10 percent or less, the discharge obtained from the stage-to-discharge relation was then used as the bankfull discharge and the recurrence interval of this discharge was calculated. If the two discharges differed by more than 10 percent, however, the site and reach selection, discharge measurements, elevations of bankfull indicators, and development of the stage-to-discharge relation were reviewed for sources of error. If no errors were found, the discharge that better fit the expected 1.5-year bankfull recurrence interval was chosen.

Preliminary data analysis of bankfull discharge at eight sites (Little Tonawanda Creek Tributary near Batavia, Ischua Creek Tributary near Machias, Ball Creek at Stow, Little Tonawanda Creek at Linden, Cayuga Creek near Lancaster, Cazenovia Creek at Ebenezer, Catatonk Creek Northwest of Owego, and Conewango Creek at Waterboro, fig. 1B) showed that the recurrence interval of bankfull discharge was considerably less than the anticipated minimum recurrence interval of 1 year. All cross sections at these sites were revisited in the spring of 2004, when the watersurface elevation of bankfull flow at each cross section was reevaluated, and the upper extent of scour lines and bankfull indicators on the flood plain were examined for evidence of recent high flows (Rosgen, 1996). The water-surface elevation of bankfull flow at all cross sections was then adjusted, and the revised data used to rerun HEC-RAS analyses. The results of these analyses are presented in table 1.

Possible explanations for the initial underestimation of bankfull stage are: (1) more than one clearly visible bankfull indicator was present, (2) one bank was appreciably higher than the other (Gordon and others, 1992), (3) no clear break between the stream bank and the flood plain was evident (Gordon and others, 1992), and (4) bankfull indicators were obscured by dense vegetation.

\section{Regional Equations for Bankfull Discharge and Channel Characteristics of Streams}

The relations between drainage-area size and bankfull discharge, depth, width, and cross-sectional area were developed for Region 6 from data from all 14 sites and are presented below. The period of record, drainage area, bankfull discharge and associated recurrence intervals, and Rosgen (1994) stream type for each site are summarized in table 1.

\section{Regionalized Relation between Bankfull Discharge and Drainage-Area Size}

The equation for streams in Region 6 (fig. 2) was: bankfull discharge $\left(\mathrm{ft}^{3} / \mathrm{s}\right)=48.0\left(\text { drainage area, in } \mathrm{mi}^{2}\right)^{0.842}$ and had a coefficient of determination $\left(\mathrm{R}^{2}\right)$ of 0.90 . The 95-percent confidence and prediction intervals for the equation are shown in figure 2 . The 95 -percent confidence interval denotes the range within which there is a 95-percent probability that equations derived from data collected on another set of 
Table 1. Characteristics of streamflow-gaging stations surveyed in Region 6 in New York, 2002-03.

$\left[\mathrm{mi}^{2}\right.$, square miles; $\mathrm{ft}^{3} / \mathrm{s}$, cubic feet per second. Site locations are shown in fig. 1B.]

\begin{tabular}{|c|c|c|c|c|c|}
\hline $\begin{array}{l}\text { Site name and USGS } \\
\text { station number }\end{array}$ & $\begin{array}{l}\text { Period(s) } \\
\text { of record }\end{array}$ & $\begin{array}{c}\text { Drainage } \\
\text { area } \\
\left(\mathrm{mi}^{2}\right)\end{array}$ & $\begin{array}{c}\text { Bankfull } \\
\text { discharge }^{1} \\
\left(\mathrm{ft}^{3} / \mathbf{s}\right)\end{array}$ & $\begin{array}{l}\text { Recurrence } \\
\text { interval of } \\
\text { bankfull } \\
\text { discharge } \\
\text { (years) }\end{array}$ & $\begin{array}{l}\text { Reach } \\
\text { stream } \\
\text { type }^{2}\end{array}$ \\
\hline $\begin{array}{l}\text { Little Tonawanda Creek Tributary near Batavia } \\
(04216875)\end{array}$ & $1976-86$ & 1.02 & $40^{3}$ & 1.01 & C6 \\
\hline $\begin{array}{l}\text { Stony Brook Tributary at South Dansville } \\
(04224807)\end{array}$ & $\begin{array}{l}\text { 1977-82, } \\
\text { 1984-91, } \\
\text { 1996-present }\end{array}$ & 3.15 & 154 & 2.05 & $\mathrm{~B} 4 \mathrm{c}$ \\
\hline $\begin{array}{l}\text { Ischua Creek Tributary near Machias } \\
(03010734)\end{array}$ & $\begin{array}{l}\text { 1978-81, } \\
\text { 1983-present }\end{array}$ & 5.12 & $90^{3}$ & 1.03 & $\mathrm{C} 5, \mathrm{C} 5 \mathrm{c}-$ \\
\hline Cuthrie Run near Big Flats (01530301) & $\begin{array}{l}1976, \\
1979-81, \\
1983-\text { present }\end{array}$ & 5.39 & 265 & 1.82 & $\mathrm{~B} 3 \mathrm{c}$ \\
\hline Big Creek near Howard (01521596) & 1977-present & 6.32 & 299 & 2.10 & $\mathrm{~B} 4 \mathrm{c}$ \\
\hline Ball Creek at Stow (03013800) & $\begin{array}{l}\text { 1955-65, } \\
\text { 1967-68, } \\
\text { 1974-present }\end{array}$ & 9.06 & $580^{3}$ & 1.10 & $\mathrm{C} 4$ \\
\hline Little Tonawanda Creek at Linden (04216500) & $\begin{array}{l}\text { 1913-68, } \\
\text { 1970-72, } \\
\text { 1977-present }\end{array}$ & 22.1 & $350^{3}$ & 1.02 & $\mathrm{C} 4$ \\
\hline Cayuga Inlet near Ithaca (04233000) & 1937-present & 35.2 & 794 & 1.35 & $\mathrm{C} 4$ \\
\hline Catherine Creek at Montour Falls (04232200) & $\begin{array}{l}\text { 1957-62, } \\
1964-66, \\
1970, \\
1976-77, \\
1987-\text { present }\end{array}$ & 41.1 & 1150 & 2.35 & $\mathrm{C} 4$ \\
\hline Fivemile Creek near Kanona (01528000) & 1937-95 & 66.8 & 1330 & 1.82 & $\mathrm{C} 3$ \\
\hline Cayuga Creek near Lancaster (04215000) & $\begin{array}{l}\text { 1938-68, } \\
\text { 1971-present }\end{array}$ & 96.4 & $3150^{3}$ & 1.12 & $\mathrm{C} 3$ \\
\hline Cazenovia Creek at Ebenezer (04215500) & 1940-present & 135 & $6400^{3}$ & 1.70 & $\mathrm{C} 4$ \\
\hline $\begin{array}{l}\text { Catatonk Creek Northwest of Owego } \\
(01514801)\end{array}$ & 1988-present & 151 & $3700^{3}$ & 1.80 & $\mathrm{C} 4$ \\
\hline Conewango Creek at Waterboro (03013000) & $1938-93$ & 290 & $2820^{3}$ & 1.33 & $\mathrm{C} 4$ \\
\hline
\end{tabular}

\footnotetext{
${ }^{1}$ From stage-to-discharge relation except as noted

${ }^{2}$ From Rosgen (1994): B3c: low-gradient, moderately entrenched, riffle-dominated channel with cobbles, B4c: low-gradient, moderately entrenched, riffle-dominated channel with gravel, C3: low-gradient alluvial channel with cobbles, C4: low-gradient alluvial channel with gravel, C5: low-gradient alluvial channel with sand, C5c-: very low-gradient alluvial channel with sand, C6: low-gradient alluvial channel with silt and clay; channel materials from longitudinal-profile pebble count.

${ }^{3}$ Discharge from HEC-RAS analysis.
} 


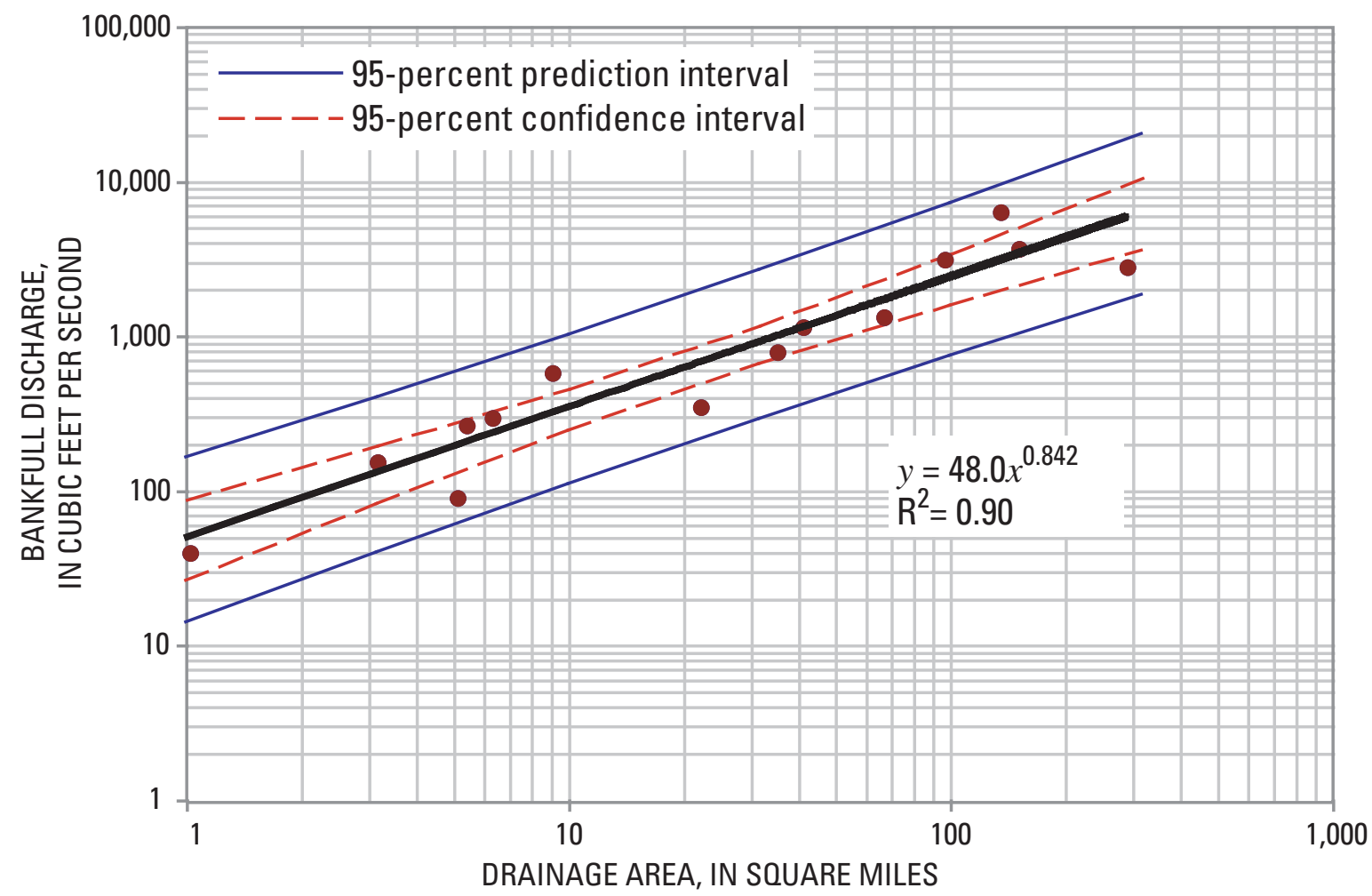

Figure 2. Graph showing bankfull discharge $(\mathrm{y})$ as a function of drainage-area size $(\mathrm{x})$ for streams surveyed in Region 6 in New York, with 95-percent confidence and prediction intervals for all sites.

streams in the same region would fall, whereas the wider 95percent prediction interval in the comparison denotes the range within which there is a 95-percent probability that bankfull discharge estimated for a single stream of a given drainage area sampled in the region would fall. Comparing equations developed for other regions and their 95-percent confidence and prediction intervals with those developed for streams of Region 6 can help ascertain regional differences in stream characteristics.

\section{Bankfull Discharge Recurrence Intervals}

The recurrence interval for the estimated bankfull discharge of each stream was calculated from regression equations relating measured discharges to known recurrence intervals (written commun.; Richard Lumia, 1991). Previous investigations reported that the average recurrence interval for bankfull discharge is 1.5 years and typically ranges from 1 to 2 years (Dunne and Leopold, 1978; Rosgen, 1996; Harman and Jennings, 1999). The bankfull-discharge recurrence interval obtained for streams surveyed in Region 6 ranged from 1.01 to 2.35 years (table 1), and averaged 1.54 years. Previous investigations in Regions 4 and 4a (fig. 1) estimated an average bankfull-discharge recurrence interval of 1.54 years and a range of 1.2 to 2.7 years (Miller and Davis, 2000), and those in Region 5 (fig. 1) estimated an average of 1.51 years and a range of 1.11 to 3.40 years (Westergard and others, 2005). The findings for this study are not surprising, in that bankfull indicators were initially identified using an anticipated 1.5-year recurrence interval.

\section{Stream-Channel Dimensions in Relation to Drainage-Area Size}

Regression equations for bankfull channel width, depth, and cross-sectional area for streams in Region 6 are as follows (fig. 3):

bankfull width $(\mathrm{ft})=16.9\left(\text { drainage area, in } \mathrm{mi}^{2}\right)^{0.419}$; bankfull depth $(\mathrm{ft})=1.04(\text { drainage area })^{0.244}$; and bankfull cross-sectional area $\left(\mathrm{ft}^{2}\right)=17.6$ (drainage area $)^{0.662}$.

Coefficients of determination $\left(\mathrm{R}^{2}\right)$ for these equations were $0.79,0.64$, and 0.89 , respectively. The high correlation coefficient for the equation relating drainage-area size to bankfull channel cross-sectional area indicates that much of the variation in these two variables is explained by the drainage-area size alone. The lower correlation coefficients for the equations that relate drainage-area size to bankfull channel width and depth, however, indicate that other factors, such as slope and channel materials (Leopold, 1994), could also affect these relations.

The raw data for Region 6 equations and the corresponding 95-percent confidence and prediction intervals are provided in plots of mean bankfull width, depth, and crosssectional area as a function of drainage-area size in figures $4 \mathrm{~A}$ through 4C. 


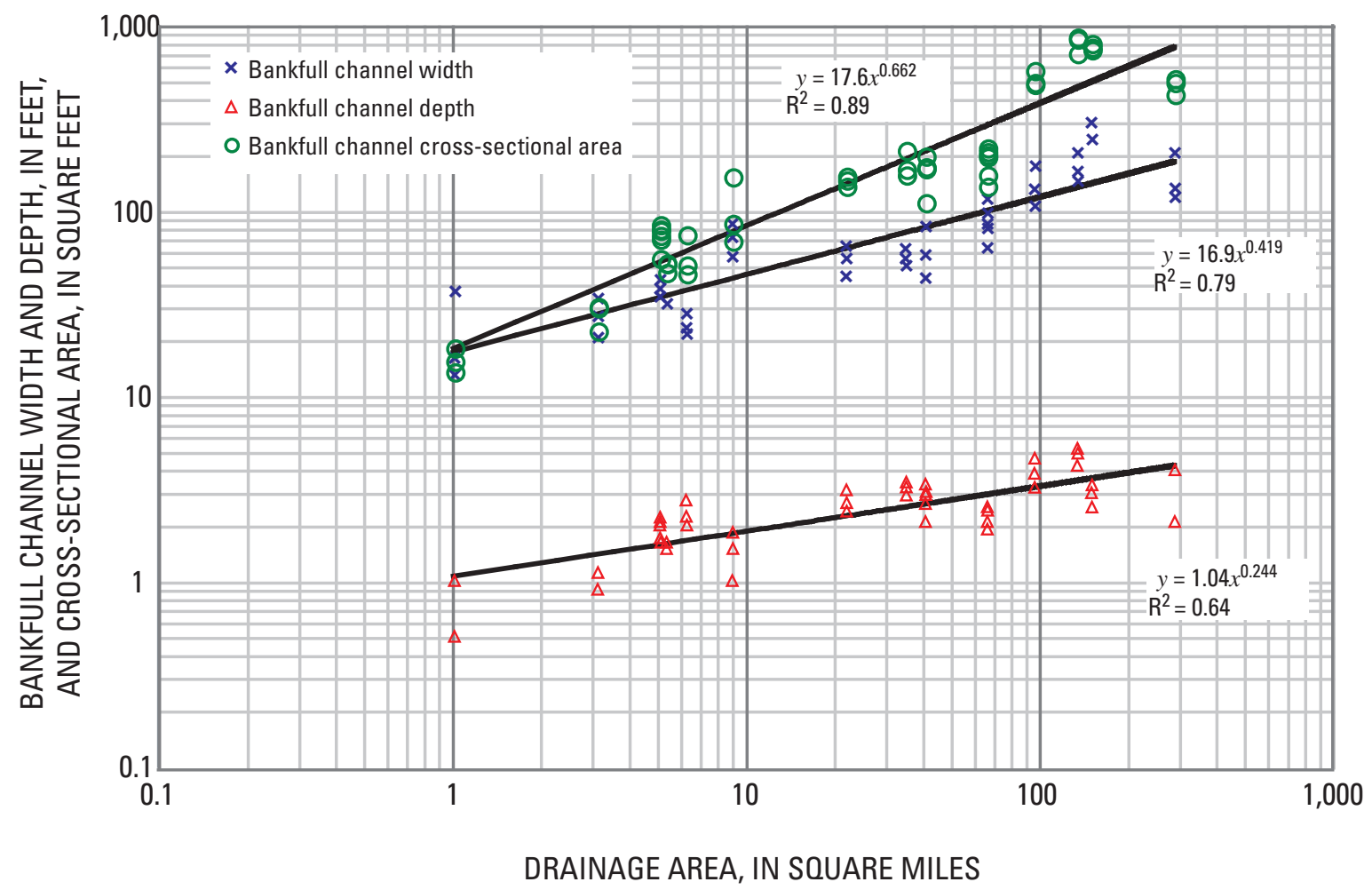

Figure 3. Graph showing bankfull channel width, depth, and cross-sectional area $(y)$ as a function of drainage-area size $(x)$ for all streams surveyed in Region 6 in New York, with best-fit lines, regression equations, and coefficient of determination $\left(\mathrm{R}^{2}\right)$ values.

\section{Stream and Reach Classification}

The Rosgen classification system (Rosgen, 1996) categorizes streams on the basis of channel morphology to provide consistent, quantitative descriptions of stream condition (Harman and Jennings, 1999). The current study used the following criteria and measurements to classify streams; the values measured in this study are given in table 2 .

- Entrenchment ratio: a field measurement of channel incision, defined as the flood-plain width divided by the bankfull width (Harman and Jennings, 1999). The floodplain width is measured at the elevation of twice the maximum stream depth at bankfull.

- Width-to-depth ratio: the bankfull width divided by the mean bankfull depth (Harman and Jennings, 1999).

- Water-surface slope: the difference between the watersurface elevation at the upstream end of a riffle and the water-surface elevation at the upstream end of another riffle at least 20 bankfull widths downstream, divided by the distance between the two riffles along the thalweg (Harman and Jennings, 1999).

- Median size (D50) of bed material: the median particle size, or the diameter that exceeds the diameter of 50 percent of all streambed particles (Harman and Jennings, 1999). D50 values were obtained through a modified Wolman pebble count (Harrelson and others, 1994)
- Sinuosity: stream length divided by valley length (Harman and Jennings, 1999).

Each reach was classified by Rosgen stream type based on the average of stream channel metrics taken each at cross section (table 1). Each cross section was also separately classified by Rosgen stream type (table 2). Stream types "A" through "G" indicate seven major stream categories that differ in entrenchment, gradient, width/depth ratio, and sinuosity. Within each major category, the numbers 1 through 6 are assigned to delineate dominant channel materials from bedrock to silt/clay along a continuum of gradient ranges (Rosgen, 1996).

All cross sections were the same stream type as the entire reach. Most of the streams surveyed were C-type reaches; the rest were B-type (table 2). All of the B reaches had slopes less than 0.02 and, therefore, were classified as $\mathrm{Bc}$ reaches (Rosgen, 1996).

\section{Region 6 Equation in Relation to those Developed for Other Areas}

The Region 6 equation for the relation between bankfull discharge and drainage-area size was compared with the corresponding equations for three other regions in New York State and one in Pennsylvania (fig. 5). The apparent similarity 

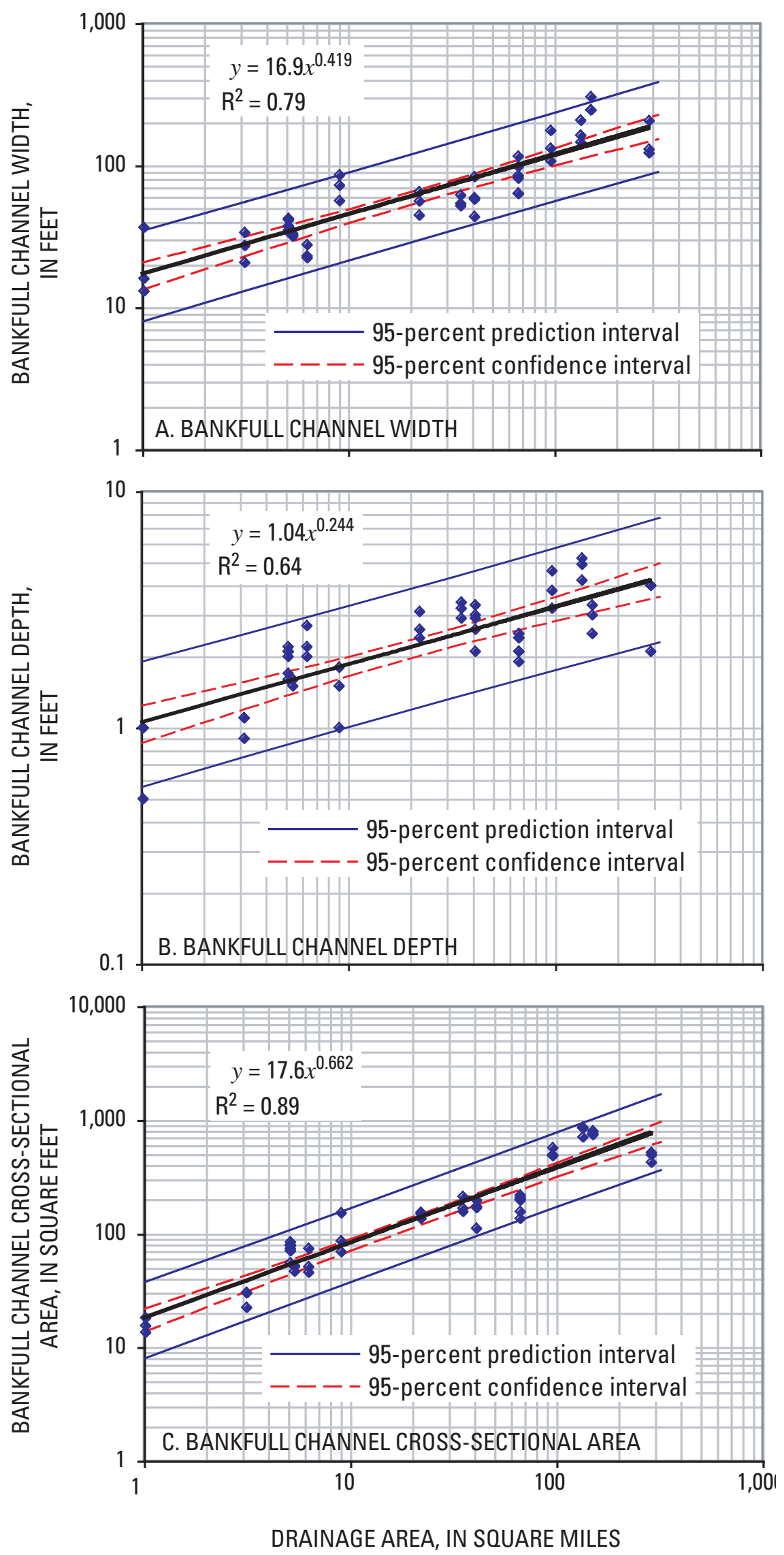

Figure 4. Graph showing mean channel dimensions as a function of drainage-area size for streams in Region 6 in New York, with 95-percent confidence and prediction intervals: A. Bankfull channel width. B. Bankfull channel depth. C. Bankfull channel cross-sectional area. 


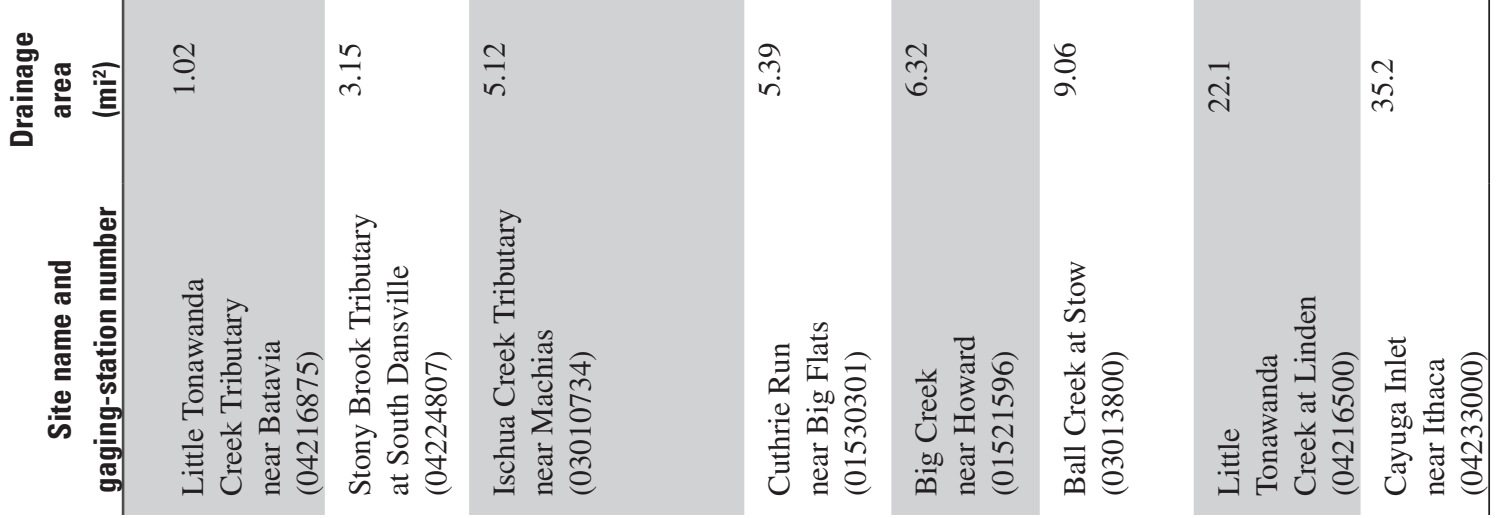




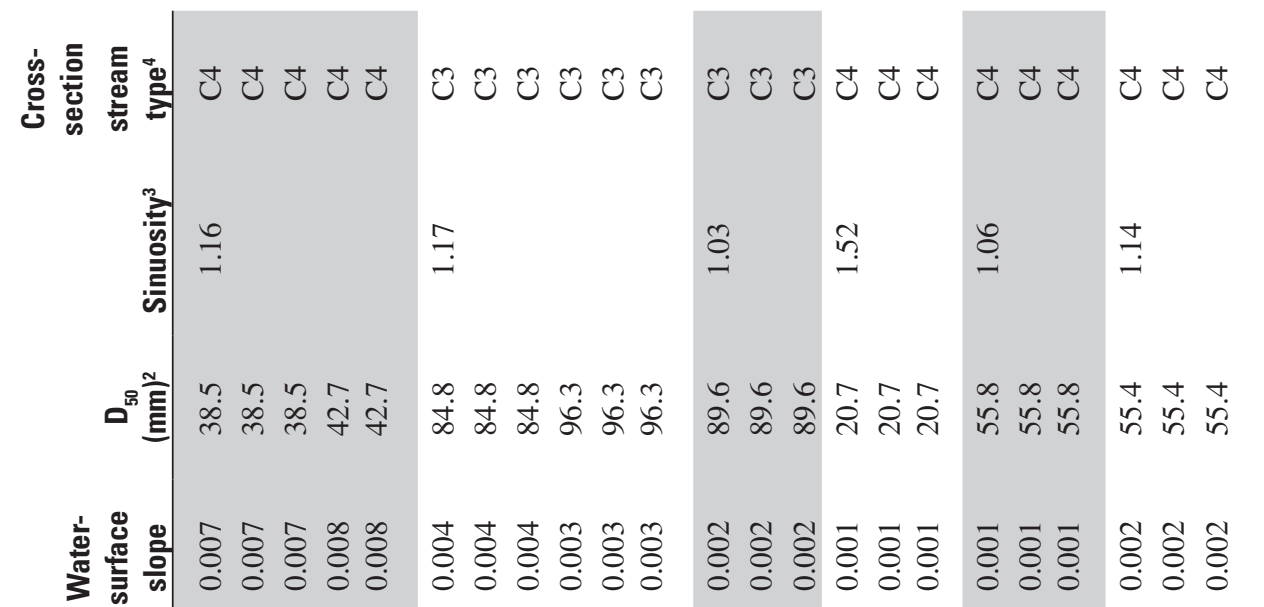

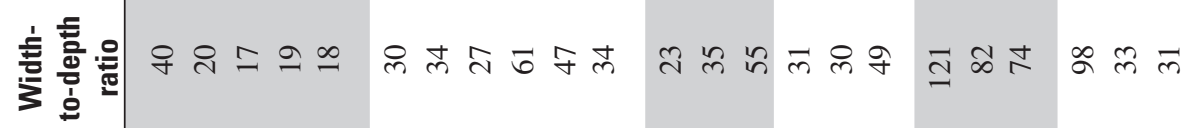

峑

들

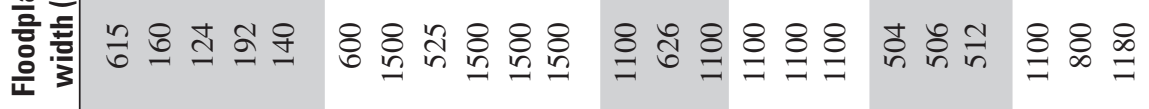

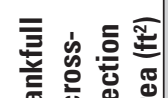

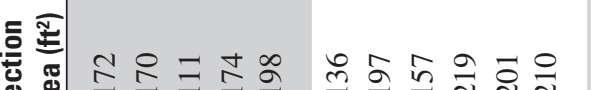

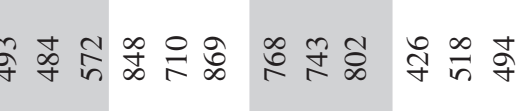
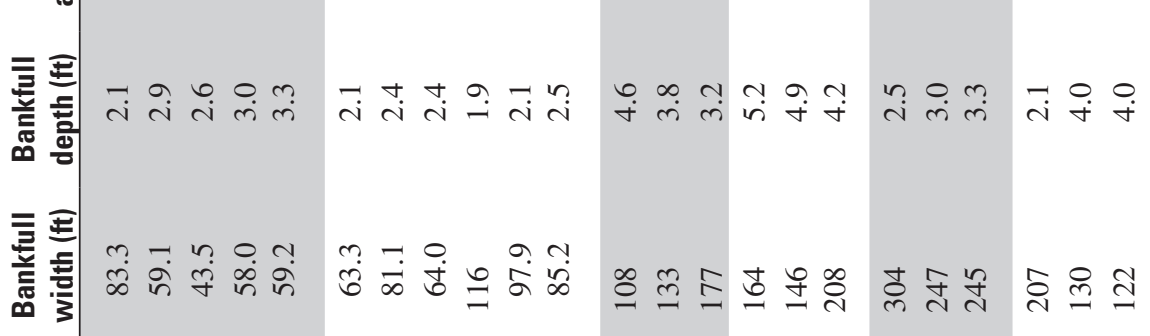

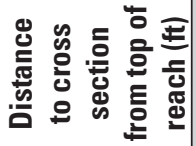

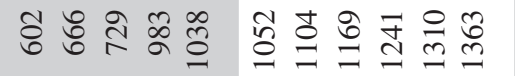

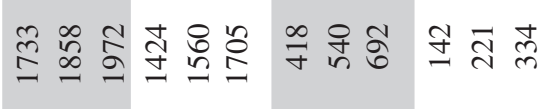

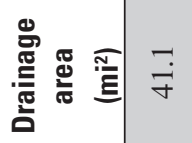

$\stackrel{\infty}{\dot{8}}$

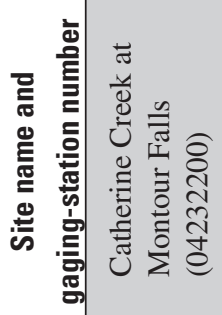

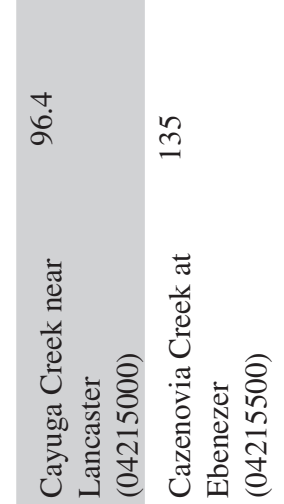

$\underline{n}$

임

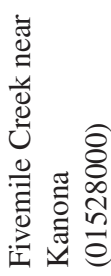

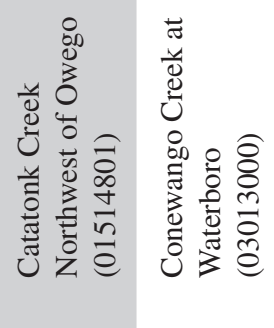

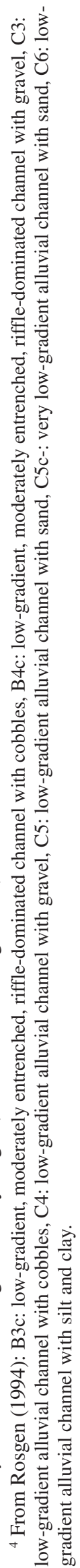



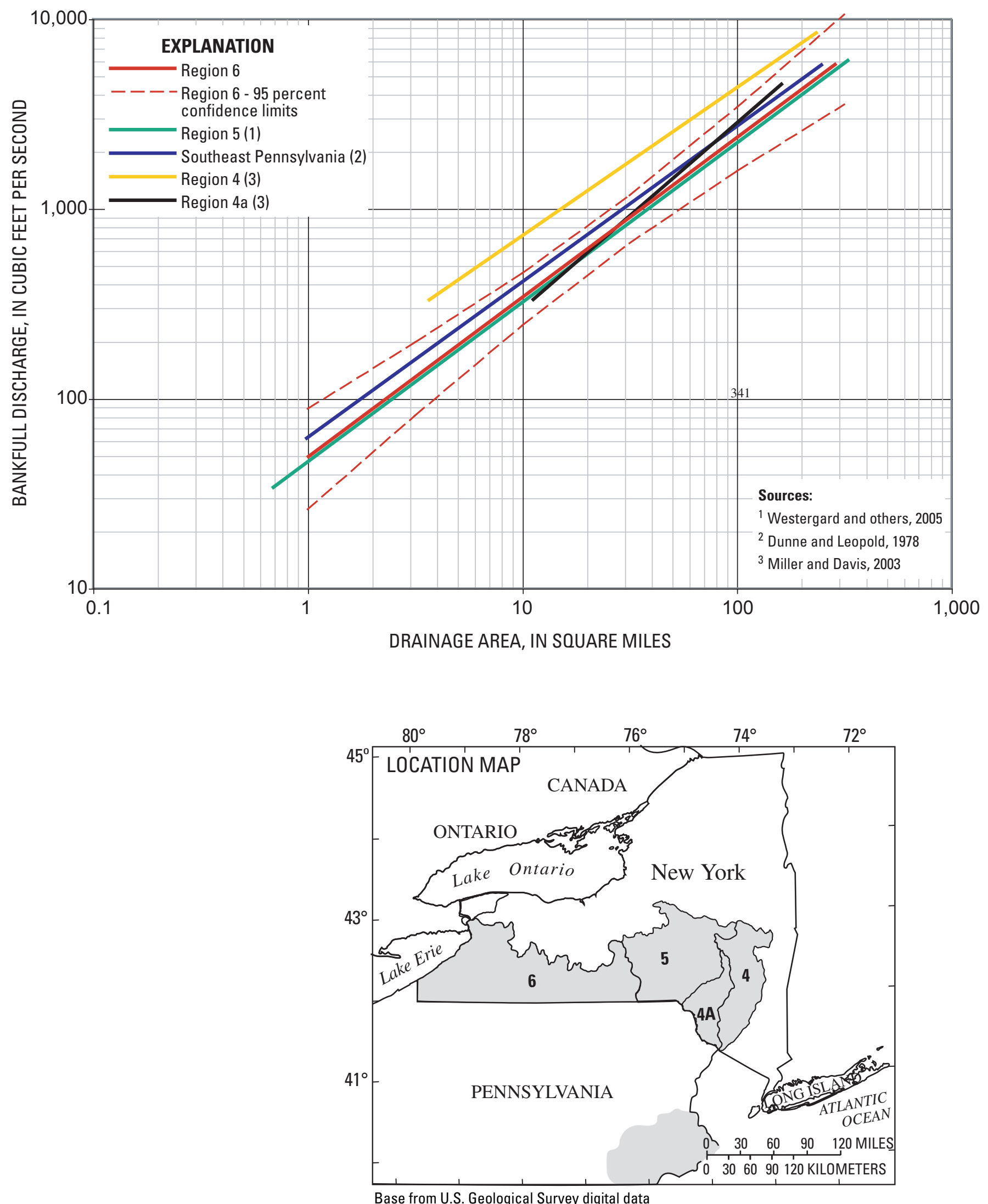

Figure 5. Graph showing bankfull discharge as a function of drainage-area size for Region 6 in New York, and published curves for four other regions in the Northeast. 
among most of the curves may reflect physiographic similarity among the regions. The slope of the Region 6 curve is similar to that of the Region 5 curve (Westergard and others, 2005) and the southeastern Pennsylvania curve (Dunne and Leopold, 1978). Both of these curves and the Region 4 curve (Miller and Davis, 2003) lie within the 95-percent confidence interval of the Region 6 curve. Differences are evident, however, and indicate a need to develop equations by region before applying them in local planning and design. For example, the New York Region 4a curve (Miller and Davis, 2003) has a much steeper slope than the other curves, possibly as a result of the steep topography in this mountainous region. This steep topography can cause greater bankfull flows than in flatter areas. The Region 4 curve, which lies above the upper bound of the 95-percent confidence interval for Region 5, is probably also affected by steep topography.

\section{Limitations of This Study}

An assumption made in this study-that the bankfull discharge was within the 1- to 2-year recurrence-interval range-may be an oversimplification (Thorne and others, 1997), even though similar recurrence intervals have been estimated in other regions in New York State (Westergard and others, 2005; Miller and Davis, 2003) and outside New York State (Harman and Jennings, 1999; Rosgen, 1994). For example, identification of bankfull indicators during the initial site inspections assumed a 1- to 2-year recurrence interval, but if the bankfull recurrence interval at a site were longer or shorter than that frequency, the bankfull channel could be incorrectly identified (White, 2001).

An additional limiting factor in the strength of the results of this study was the small number of active USGS streamflow-gaging stations in Region 6. Nine of the 14 sites surveyed had gages that measured peak flows only, and three had inactive gages. The lack of complete data from the peakflow-only sites required two assumptions: (1) the annual peaks on which recurrence-interval data are based were always at or above bankfull stage, and (2) the computer-generated stageto-discharge rating accurately reflected current hydrologic conditions. Similarly, the lack of recent data from the inactivegage sites required three assumptions: (1) the recurrence interval of bankfull discharge had not changed since the site was last active (flood-frequency analysis was performed for active periods of each site), (2) the channel pattern at the site had not been noticeably altered by floods, diversions, ground-water recharge, or changes in land use since the site was discontinued, and (3) three to five low- to medium-flow discharge measurements were sufficient to define a stage-todischarge relation that could reliably be extended to define a bankfull discharge. The violation of any of these conditions could result in a change in the recurrence interval of bankfull discharge and, subsequently, the misidentification of bankfull stage.
Regional channel-geometry equations can be more reliable than statewide equations in the design of streamrestoration projects, enhancement of fish habitat, and adjustment of other in-stream and riparian structures (Castro and Jackson, 2001) because they incorporate local characteristics that directly affect channel geometry. Users of regional equations need to recognize the limitations of these relations, however, and accept that they are designed only to provide general estimates of bankfull-channel dimensions and discharges (White, 2001) and do not obviate the need for field measurement and verification of bankfull stream-channel dimensions.

\section{Summary and Conclusions}

Equations relating bankfull discharge and channel dimensions (width, depth, and cross-sectional area) to the size of the drainage area at gaged streams are needed to predict bankfull discharge and channel dimensions at ungaged streams and to provide information for the design of stream-restoration projects. The USGS, in cooperation with the NYS DEC and the NYS DOT, undertook a study to develop these equations for streams in western New York (Region 6). Eleven active and 3 inactive sites were chosen according to established guidelines. Stream-survey data and discharge records from these sites were used in regression analyses to relate bankfull discharge and bankfull channel width, depth, and crosssectional area to the size of the drainage area. The resulting equations were:

bankfull discharge $\left(\mathrm{ft}^{3} / \mathrm{s}\right)=48.0\left(\text { drainage area, in } \mathrm{mi}^{2}\right)^{0.842}$ bankfull channel width $(\mathrm{ft})=16.9(\text { drainage area })^{0.419}$ bankfull channel depth $(\mathrm{ft})=1.04$ (drainage area) ${ }^{0.244}$ bankfull channel cross-sectional area $\left(\mathrm{ft}^{2}\right)=17.6$ (drainage area) $^{0.662}$

The high coefficient of determination $\left(\mathrm{R}^{2}\right)$ for the equations describing bankfull discharge and cross-sectional area ( 0.90 and 0.89 , respectively) indicate that much of the variation in these variables is explained by the size of the drainage area. The lower correlation coefficients for bankfull channel width and depth ( 0.79 and 0.64 , respectively) indicate that drainage-area size alone cannot be used to predict these variables accurately.

Recurrence intervals were calculated for the estimated bankfull discharge of each stream, using regression equations relating measured discharges to known recurrence intervals. The recurrence intervals for bankfull discharge of surveyed streams in Region 6 ranged from 1.01 to 2.35 years, with a mean recurrence interval of 1.54 years. Streams were classified by Rosgen stream type on the basis of specific channel characteristics at each surveyed cross-section. Most streams contained C-type reaches, with occasional B-type reaches.

The Region 6 equation for the relation between bankfull discharge and drainage-area size was compared with equations 


\section{Regionalized Equations for Bankfull Discharge and Channel Characteristics of Streams in New York State: Hydrologic Region 6 in the Southern Tier of New York}

developed for four other parts of New York State and southeastern Pennsylvania. The differences among results indicate that, although similar regions have similar relations between bankfull discharge and channel characteristics, the equations need to be refined by region to improve their accuracy when they are applied to local planning and design efforts.

\section{Acknowledgements}

Thanks are extended to Daniel Davis, Sarah Miller, and Elizabeth Reichheld (NYCDEP); and Rene VanSchaack, Douglas Dekoskie, Joel Dubois, and Jake Buchanan (Greene County Soil and Water Conservation District) for advice on geomorphology training and on survey and data analysis and methods of interpretation. Thanks also to Richard Lumia (USGS) for calculating recurrence intervals, and to Matthew Horn, Rebecca Pratt, and Dana Warren (Cornell University) for assistance in the field.

\section{References Cited}

Annable, W.K., 1996, Morphologic relationships of rural watercourses in southern Ontario and selected field methods in fluvial geomorphology: Toronto, Ontario Ministry of Natural Resources, 92 p.

Brunner, G.W., 1997, HEC-RAS River analysis system user's manual: U.S. Army Corps of Engineers CPD-68, 205 p.

Castro, J.M., and Jackson, P.L., 2001, Bankfull discharge recurrence intervals and regional hydraulic geometry relationships-patterns in the Pacific Northwest, USA: Journal of the American Water Resources Association, v. 37, no. 5, p. 1249-1262.

Dalrymple, Tate, and Benson, M.A., 1967, Measurement of peak discharge by the slope-area method: U.S. Geological Survey Techniques of Water-Resources Investigations, book 3, chap. A2, 12 p.

Dunne, Thomas, and Leopold, L.B., 1978, Water in environmental planning: San Francisco, W.H. Freeman, 818 p.

Gordon, N.D. McMahon, T.A., and Finlayson, B.L., 1992, Stream hydrology: an introduction for ecologists: New York, John Wiley and Sons, $526 \mathrm{p}$.

Harman, W.A., and Jennings, G.D., 1999, River course-application of the Rosgen stream classification system to North Carolina: Raleigh, N.C., North Carolina Cooperative Extension Service, accessed October 5, 2002, at: (http://www.bae.ncsu.edu/programs/extension/wqg/sri/rvcrs2.pdf).

Harrelson, C.C., Rawlins, C.L., and Potyondy, J.P., 1994, Stream channel reference sites - an illustrated guide to field technique: Ft. Collins, Colo, U.S. Forest Service Rocky Mountain Research Station, General Technical Report RM-245, 61 p.
Jaquith, Shayne, and Kline, Michael, 2001, Vermont regional hydraulic geometry curves: Waterbury, Vt., Vermont Water Quality Division, accessed March 6, 2003, at: (http://www.anr.state.vt.us/dec/waterq/ rivers/docs/rv_hydraulicgeocurves.pdf).

Jarrett, R.D., and Petsch, H.E., 1985, Computer program NCALC user's manual-verification of Manning's Roughness Coefficient in channels: U.S. Geological Survey Water-Resources Investigations Report 85-4317, 27 p.

Kennedy, E.J., 1984, Discharge ratings at gaging stations: U.S. Geological Survey Techniques of Water-Resources Investigations, book 3, chap. A10, 59 p.

Leopold, L.B., 1994, A view of the river: Cambridge, Mass., Harvard University Press, 298 p.

Leopold, L.B., Wolman, M.G., and Miller, J.P., 1964, Fluvial processes in geomorphology: San Francisco, W.H. Freeman, 522 p.

Lumia, Richard, 1991, Regionalization of flood discharges for rural, unregulated streams in New York, excluding Long Island: U.S. Geological Survey Water-Resources Investigations Report 90-4197, $119 \mathrm{p}$.

Miller, S.J., and Davis, Daniel, 2003, Identifying and optimizing regional relationships for bankfull discharge and hydraulic geometry at USGS stream gage sites in the Catskill Mountains, N.Y.: New York City Department of Environmental Protection Technical Report, 24 p.

Powell, R.O., Miller, S.J., Westergard, B.E., Mulvihill, C.I., Baldigo, B.P, Gallagher, A. and Starr, R.R., 2004, Guidelines for surveying bankfull-discharge geometry and developing regional hydraulicgeometry models for streams of New York State: U.S. Geological Survey Open-File Report 03-92, 26 p., online only.

Rosgen, D.L., 1994, A classification of natural rivers: Catena, v. 22, no. 3, p. 169-199.

Rosgen, D.L., 1996, Applied river morphology: Pagosa Springs, Colo., Wildland Hydrology, 388 p.

Thorne, C.R., Hey, R.D., and Newson, M.D., 1997, Applied fluvial geomorphology for river engineering and management: Chichester, U.K., John Wiley and Sons, 376 p.

Westergard, B.E., Mulvihill, C.I., Ernst, A.G., and Baldigo, B.P., 2005, Regionalized equations for bankfull-discharge and channel characteristics of streams in New York State: Hydrologic region 5 in Central New York: U.S. Geological Survey Scientific Investigations Report 2004-5247, 16 p, online only.

White, K.E., 2001, Regional curve development and selection of a reference reach in the non-urban lowland sections of the Piedmont Physiographic Province, Pennsylvania and Maryland: U.S. Geological Survey Water-Resources Investigations Report 01-4146, 20 p.

Wolman, M.G. and Miller, J.P., 1960, Magnitude and frequency of forces in geomorphic process: Journal of Geology, v. 69, p. 54-74. 